\title{
Triphala: A Wonder Drug of Ayurveda
}

\author{
Anshul Alwadhi \\ Associate Professor \& HOD, L.B.S Ayurvedic College, Bilaspur, Yamunanagar, Haryana, India.
}

\begin{abstract}
Triphala is used in the traditional Indian system of medicine. Triphala is composed of three fruits namely Haritaki, Vibhitaki, Amalaki. The fruit of three together called Triphala. It is widely prescribed Ayurvedic drug and is used in various diseases. Triphala is a traditional Ayurvedic formula that tones and supports normal function to the bowel. This three fruit formula is simply a bowel toner, designed to store the muscular function and contractibility of the intestinal wall. It is used as an anti oxidant and possesses various beneficial properties.
\end{abstract}

Keywords: Triphala, Ayurveda, Charak Samhita, Sushruta Samhita, Astanga Hridaya

\section{INTRODUCTION}

The objective of this scientific knowledge is to enable physician to make judicious use in a more effective way. Looking to the prime importance of Prayoga (use), Acharya Charak has said that real expert of medicinal plants is he who is well versed in their use besides their name and forms ${ }^{1}$. The present article deals with classical use of Triphala in various Diseases. Group of drugs like Triphala are very popular in society. Now a large number of people are using Triphala rather than taking singly as Haritaki, Vibhitaki or Amalaki. Therefore a classical review of Triphala is needed. During each meal, the intestinal tract produces a certain amount of mucus that helps in lubricating it. Triphala which is an Ayurvedic herbal formula, helps to cleanse the mucus of the digestive villi, making for a more effective digestive process. Triphala has three fruits that support the elimination process. Amalaki is a fruit that supports intestinal repair. Bibhitaki pulls the old mucus of the wall. Haritaki strengthens the intestinal muscles to contract more efficiently when the bowels need to move.

AIM: To study drug review of Triphala from Ayurvedic texts.

\section{Objective:}

1. Collection of various references of Triphala from available Ayurvedic texts.

2. Enlightening the use of Triphala in various Ayurvedic texts.

\section{MATERIALS AND METHODS}

Materials: All references of Triphala were collected from Original text of Charak Samhita. Sushrut Samhita, Ashtanga Hridayam.

Methods: References of Triphala was collected from original text and arranged with their use in various diseases. All the diseases are grouped according to Ashtanga Ayurveda.

\section{Kaya Chikitsa: \\ Chronic Fever:}

1. Triphala, Haritaki, Guduchi, and Pippali each separately should be given according to the prescribed methods or Bhallataka mixed with jaggery may be used $^{2}$.

2. One suffering from fever should take Triphala and Pippali with honey ${ }^{3}$.

\section{OBESITY:}

1. Decoction of Triphala mixed with honey reduces fat ${ }^{4}$. 
2. Use of Buttermilk and Nimba, rough food, drinks and drug, urine and Triphala is the remedy for the disorder of lipid metabolism ${ }^{5}$.

Heart Diseases: In heart diseases caused by Kapha one should take Phaladi or Mustadi drugs or Triphala alone ${ }^{6}$.

Prameha: For Ksarameha, Triphala decoction is the remedy ${ }^{7}$.

Kustha: Triphala, Vidanga and Pippali should be taken with oil, ghee and honey ${ }^{8}$.

Vatarakta: One should take Triphala powder mixed with Trikatu and honey or Guggulu or Shilajatu with cow's urine'

\section{Shalya Chikitsa:}

Fistual in ano: Powder of Triphala and catechu impregnated with decoction of Triphala and mixed with equal quantity of Guggulu and honey destroys Kustha, Diabetic boils and fistula in ano ${ }^{10}$.

Wounds: Triphala Guggulu is the best remedy for wounds ${ }^{11}$.

\section{Agad Chikitsa}

\section{Snake Poison:}

Old Ghee mixed with Triphala powder should be taken ${ }^{12}$.

\section{Shalakya Chikitsa:}

\section{Eye Diseases:}

1. Triphala is the best remedy for eye diseases ${ }^{13}$.

2. If one takes regularly old Ghee, Triphala, satavari, Patola, Mudga, Amalaka, and Barley there is no fear of Timira for him ${ }^{14}$.

3. One suffering from defects of vision should use regularly Triphala decoction with ghee or cakes etc. Prepared with Triphala, cooled and added with honey and sugar ${ }^{15}$.

4. To improve eye-sight, one should use Triphala with honey and Ghee at night $^{16}$.

\section{Rasyana Chikitsa:}

Triphala Rasayana ${ }^{17}$.

\section{DISCUSSION}

One of the herbal drugs like Triphala has a lot of significance in our life as it cures many diseases. After reviewing various classical texts it is clear that we can cure different diseases by using triphala. Triphala has many medicinal properties such as Lekhaniya, Kushathaghna, Krimighna and Sirovirechaniya etc. In the Ayurvedic literature Triphala is extensively described. It is used internally and externally in various diseases. In the Ayurvedic literature it is one of the most important commonly used herbs. Presently it is considered as an important anti-diabetic and anti-oxidant drug. Anti-oxidant scavenge molecules in the body known as free radicals, which damage cell membranes, tamper with DNA, and even causes cell death. Most important thing about Triphala is that it is cultivated throughout India.

\section{CONCLUSION}

After reviewing the Ayurvedic classical texts, it is clear that Triphala is used in the traditional system of medicine to cure various diseases. Triphala is drug widely used in many disorders due to various pharmacological actions. Presently it is considered as an important anti-diabetic and anti-oxidant drug.

\section{Acknowledgement: None}

\section{Conflict of Interest: None}

\section{Source of Funding: None}

\section{REFERENCES}

1. Agnivesh, Charak Samhita with Ayurveda Deepika commentry by Chakrapani Datta Edited by Yadav ji Trikamji Acharya, Chaukhamba Prakashan Edition 2007, Sutrasthana-1/121, Page-22

2. Vagbhata, Ashtanga Hridayam with commentaries of Arunadatta and of Hemadri Edited by Bhisagacharya Harisastri Paradkara Vaidya, Chaukhambha Orientalia, Edition 2005, Chikitsasthana1/154, Page-571 
3. Sushruta, Sushruta Samhita with Hindi translation by Shastri Ambika Dutta, Chaukhambha Sanskrit Sansthan, Edition2006, Uttarsthan-39/302, Page-207

4. Vagbhata, Ashtanga Hridayam with commentaries of Arunadatta and of Hemadri Edited by Bhisagacharya Harisastri Paradkara Vaidya, Chaukhambha Orientalia, Edition 2005, Sutrasthana-14/22, Page-226

5. Agnivesh, Charak Samhita with Ayurveda Deepika commentry by Chakrapani Datta Edited by Yadav ji Trikamji Acharya, Chaukhamba Prakashan Edition 2007, Sutrasthana-13/78, Page-86

6. Sushruta, Sushruta Samhita with Hindi translation by Shastri Ambika Dutta, Chaukhambha Sanskrit Sansthan, Edition2006, Uttarsthan-43/18, Page-282

7. Sushruta, Sushruta Samhita with Hindi translation by Shastri Ambika Dutta, Chaukhambha Sanskrit Sansthan, Edition2006, Chikitsasthan-11/9, Page-60

8. Agnivesh, Charak Samhita with Ayurveda Deepika commentry by Chakrapani Datta Edited by Yadav ji Trikamji Acharya, Chaukhamba Prakashan Edition 2007, Chikitsasthana-7/97-99, Page-455

9. Sushruta, Sushruta Samhita with Hindi translation by Shastri Ambika Dutta, Chaukhambha Sanskrit Sansthan, Edition2006, Chikitsasthan-5/34, Page-35

10. Vagbhata, Ashtanga Hridayam with commentaries of Arunadatta and of Hemadri Edited by Bhisagacharya Harisastri Paradkara Vaidya, Chaukhambha Orientalia, Edition 2005, Uttarsthana-28/42, Page-880

11. Vagbhata, Ashtanga Hridayam with commentaries of Arunadatta and of Hemadri Edited by Bhisagacharya Harisastri
Paradkara Vaidya, Chaukhambha Orientalia, Edition 2005, Uttarsthana-40/56, Page-944

12. Vagbhata, Ashtanga Hridayam with commentaries of Arunadatta and of Hemadri Edited by Bhisagacharya Harisastri Paradkara Vaidya, Chaukhambha Orientalia, Edition 2005, Uttarsthana-36/69, Page-912

13. Vagbhata, Ashtanga Hridayam with commentaries of Arunadatta and of Hemadri Edited by Bhisagacharya Harisastri Paradkara Vaidya, Chaukhambha Orientalia, Edition 2005, Uttarsthana-40/50, Page-944

14. Sushruta, Sushruta Samhita with Hindi translation by Shastri Ambika Dutta, Chaukhambha Sanskrit Sansthan, Edition2006, Uttarsasthan-17/48, Page-63

15. Vagbhata, Ashtanga Hridayam with commentaries of Arunadatta and of Hemadri Edited by Bhisagacharya Harisastri Paradkara Vaidya, Chaukhambha Orientalia, Edition 2005, Uttarsthana-13/1718, Page-819

16. Vagbhata, Ashtanga Hridayam with commentaries of Arunadatta and of Hemadri Edited by Bhisagacharya Harisastri Paradkara Vaidya, Chaukhambha Orientalia, Edition 2005, Sutrasthana-8/44, Page-157

17. Agnivesh, Charak Samhita with Ayurveda Deepika commentry by Chakrapani Datta Edited by Yadav ji Trikamji Acharya, Chaukhamba Prakashan Edition 2007, Chikitsasthana-1/3/41-47, Page-385

How to cite this article: Alwadhi A. Triphala: a wonder drug of ayurveda. Int J Health Sci Res. 2021; 11(7): 314-316. DOI: https://doi.org/10. 52403/ijhsr.20210743 